\title{
The Use of Online Media as A Means of Marketing Communication for Msmes in Bandung
}

\author{
Hasim \\ Universitas Kebangsaan \\ Email: Hasim.kbm@gmail.com
}

\begin{tabular}{l} 
ARTICLE INFO \\
\hline Date received : 03 January 2021 \\
Revision date : 02 February 2021 \\
Date received : 01 March 2021
\end{tabular}

Keywords:

Media; marketing

communications; UMKM

\begin{abstract}
The change in human mindset in marketing products departs from the rapid development of communication and information technology, and at this time the world leads to online services. This study departs from the initial observations of researchers related to MSMEs in The City of Bandung which is so much accompanied by good government attention. UMKM data recorded in the office of micro and medium enterprises cooperatives in the city of Bandung amounted to 6140 people, thus showing that the city of Bandung became the center of young business people. The number of MSMEs that are so much needed a proper and effective marketing communication so that the products offered can be in demand by consumers. Departing from some of these images this research reveals the marketing methods of MSMEs, and describes the form of marketing communication of MSMEs through online media. Based on the theme raised in this study, researchers set the research method using qualitative method with deskrptif approach. The results of this study describe that marketing methods are done online and offline, from these two methods online marketing is considered more effective because it can reach consumers widely with relatively affordable promotional costs. The form of marketing communication of MSMEs is seen based on the type of business, but in general hamir is the same as giving information about the advantages of products offered, and differences with similar products.
\end{abstract}

\section{INTRODUCTION}

The rapid development of communication and information technology in Indonesia changes and affects people's mindsets, thus impacting the lifestyle of society in general. Communication and information technology makes it easy for people to support all activities, be it private or public or public. Indonesian society in general and the people of Bandung in particular are very fortunate with the development of technology at this time, of course the development of this technology can bring positive benefits.

The world today leads to digitization in all aspects, including the use of online media in private, public services, and trade. Online media or communication and information technology bring changes to the marketing patterns of MSMEs in The City of Bandung, which was originally only done offline. Popular online marketing media that is

\begin{tabular}{ll}
\hline How to cite: & $\begin{array}{l}\text { Hasim. (2021) The Use of Online Media as A Means of Marketing Communication for Msmes } \\
\text { in Bandung, 2(3). https://doi.org/10.46799/jsss.v2i3.130 }\end{array}$ \\
\hline E-ISSN: & $2721-5202$ \\
\hline Published by: & Ridwan Institute \\
\hline
\end{tabular}


growing in Indonesia is quite diverse, including bukalapak.com, shopee, lazada, blibi.com, tokopedia, olx, bhineka, JD.ID, instagram, and or personal-made applications of these businesses. The variety of online stores that are growing in Indonesia will certainly increase the choice in using marketing services in general, and especially MSMEs in the city of Bandung.

Bandung city is a strategic city and the center of the capital of west Java Province will thus be a lure for business people to seek profit with a variety of business activities, based on data from the office koperasai micro and medium enterprises bandung number of MSMEs as many as 6140 people. Bandung city is the choice of many people of West Java and some citizens of the capital city of Jakarta to vacation on the weekend, and of course apart from the capital city of Jakarta there are also some from other areas. The city of Bandung is increasingly preoccupied with various activities to be a promising opportunity for MSMEs in the field of services and processing of goods products. Increasingly varied products, and increasingly competitive prices, as well as the ease of transactions offered by MSMEs both through direct and online sales will attract consumers and become the main choice among the products offered by other MSMEs.

UMKM products in The City of Bandung are quite varied, including; culinary products, accessories, screen printing services, packaging, tours, and others. Marketing of MSME products requires the right means to reach the desired target, thus the products offered will be more easily known to the public at large. Online media in Indonesia today is one of the alternatives for entrepreneurs as a marketing medium because it helps to solve their problems.

Marketing of MSMEs products is not only done directly or offline but also needs to be done online, in this way the products produced by MSMEs will be more quickly known by consumers so that it will be able to increase sales and of course this will correlate with the profits obtained. Marketing using this online mechanism certainly requires thoroughness and accuracy in choosing the online media to be used and also required the ability of entrepreneurs to package marketing communication messages that will be delivered to prospective consumers. Market segmentation, product prices, product quality, and product packaging need to be symmetrized with the marketing message to be delivered, in this way it is expected to be easier to understand and capture the message by prospective consumers.

Research with the title of the use of online media as a means of marketing communication of msmes in the city of Bandung is required restrictions, in this way the research is more focused and will get the subject matter to be revealed, restrictions are carried out by setting the following research objectives: 1 . To uncover the marketing methods of MSMEs in the city of Bandung, 2. Describing the form of marketing communication of MSMEs through online media.

Marketing in general can be understood as an effort to exchange products, both in the form of goods and services, in marketing these products required proper communication so that the expectations in the business of marketing the product can be achieved well. Described Barry Callen in (Panuju, 2019) Marketing communications are anything your entire organization does that affects your customer behavior or perception. The marketing communication process is a conversation between you and your customers about what they say as you listen to your customer complaints based on those complaints you send them messages.

Further explained (Panuju, 2019) the endeavor of experts to marry communication and marketing is due to indeed in empirical reality it is almost impossible to marketing without communication. Communication is always present in every marketing, however possible marketing has been designed with modern technology so that communication is impersonal. Communication does not present people with people, but rather people with machines. Similarly, MSMEs in Bandung no longer talk to people, but have changed their marketing patterns from conventional to digital or online marketing, meaning communication conducted using technology intermediary media.

(Suwatno, 2018) explains that marketing communications relate to symbols that are close and acceptable to consumers. In order for the meaning of the message to be understood and accepted effectively, the 
symbols used (writings, images, videos) must match the character and behavior of the consumer. For this reason, marketing communication is closely correlated with consumer behavior. In addition to being closely related to behaviors that fall into the discipline of psychology, a sociologicalanthropological approach in understanding consumer behavior is also very important to obtain a distinctive and specific description of the dynamics of the character, behavior, and culture of the consumer. Research on the Use of Online Media as a Means of Marketing Communication Umkm Actors in the city of Bandung that researchers do this to see the form of marketing communication conducted by MSMEs, especially in the city of Bandung, based on the expert opinion can be possible the form of marketing conducted will be different from the form of communication conducted in other areas, meaning that in each area can be possible to have different forms of marketing communication.

Further explained (Suwatno, 2018) in the marketing communication discourse, there are 5 main disciplines or devices that become an integral part of the concept of marketing communication, namely: 1 . Advertising, 2. Sales promotion, 3. Personal selling, 4. Public relations, 5.and direct marketing. The five main components of the device can be used as a marketing strategy conducted by MSMEs, in addition to the form of marketing communication that is the goal in this study in obeservasi through the five components of marketing concepts. The form of marketing will be seen and analyzed through online marketing media used by MSMEs, the online media in question can be determined after the observation because not all MSMEs use the same type of online media.

According to Effendi in (Suryadi, 2018) Communication strategy consists of two important aspects that must be studied and understood well, namely strategies that are interpreted macro (planned multimedia strategy) and micro (single communication medium). This is very important to give complete meaning in a proper communication strategy later. Both aspects have dual functions, including: 1 . Disseminating communication messages that are informative, persuasive, and systematically instructive on the target to obtain maximum results. 2. Bridging the cultural gap, for example programs derived from another cultural product is considered good to be applied and made a cultural property itself is highly dependent on how the strategy of packaging the information. The expert explanation if the research relates to the marketing of MSMEs there is a communication strategy that needs to be considered, namely communication that has a small scope and communication that has a larger scope. The large scope of communication carried out by MSMEs in Bandung can use communication strategies through online media facilities. The selection of online media facilities that can cover the public at large even globally with the aim of the products offered is more easily known in the hope that the end of society can choose its products.

Described in the study "Online Shop Marketing Communication Strategy Babyeye_id Through Instagram Application In Improving Product Sales". Communication has a very important role in marketing activities. If communication is experiencing problems, then marketing activities will be hampered. The implementation of marketing communication aims to introduce and communicate products (goods and services) to the public. Promotions are done so that consumers know and are interested in buying and becoming customers of the products offered. The purpose of this research is to find out how marketing communication strategies conducted online shop Babyeye_id through instagram application in increasing product sales. And the second to know the factors that influence online shop Marketing Communication Strategy babyeye_id through the Instagram app in increasing product sales. The theory used is a marketing mix (4P) consisting of Product (product), Price (price), Place (place), Promotion (promotion). The research method used is qualitative method with descriptive approach. Data collection is used by interviewing, observation, and documentation. The results of this study describe marketing communication strategies conducted by the owner or owner of online shop babyeye_id, which includes Product, Price, Place then Promotion. (Universitas Muhammadiyah Sumatera Utara_ Strategi Komunikasi Pemasaran Online Shop Babyeye_Id Melalui 
Aplikasi Instagram Dalam Meningkatkan Penjualan Produk, n.d.)

In the book Communication and Human Behavior Brent, D. Ruben and Lea P. Stewart. 2013:87 explained, the existence of human communication technology also has the capacity to "move around" to bridge space. Objects or people who refer to a particular symbol do not need to be present in order for the symbol to be used in communication. Information created and packaged in one geographic location can be transmitted to people on other continents. Communication technology extends and provides alernative to communicate face-toface, as a medium of sending and receiving messages. When one considers the total spectrum of current uses of technology, including mobile phones, email, and other cable networks, for example we realize that there are not many aspects of our personal, social, and work lives that are done through perfect face-to-face communication. The media will continue to play an increasingly broad and tangible role in human activities. The existence of such technology that modern marketing is not only done conventionally or offline but can also be done online through the medium of communication and information technology, of course the selection of this media can be adjusted to the financial condition, the type of product marketed, and the interest of the MSMEs themselves.

Understanding social media in general is a tool to convey information from a person to a person or group of people, to achieve individual goals as well as group goals. Nasrulla explained in the book Social Media ( 2016 ; 8 ) (Nasrullah, 2016) that" social media can be seen from the development of how individuals relate to media devices. (Van Dijk, 2013) Van Dijk further explained (2013), in Nasrullah, Social Media. 2015:11, that "Social media is a media platform that focuses on the existence of users who facilitate them in activities and collaboration, therefore social media can be seen as an online media (facilitator) that strengthens relationships between users as well as a social bond." From the description of the understanding described by Nasrullah in the book Social Media, 2016: 13 it can be concluded that social media is a medium on the internet that allows its users to present themselves and interact, collaborate, share, and communicate with other users, and can form social bonds online.

\section{METHOD}

The design of this research is qualitatively designed, explained (Suliyanto \& MM, 2017) Qualitative research method is a research method based on the philosophy of postpositivism, used to research on natural object conditions where researchers are key instruments, data collection techniques are carried out in trangulation (combined), data analysis is inductive or qualitative and qualitative research results emphasize more on meaning. The determination of methodology in this study is based on the nature and background that the researchers describe, and the method used is descriptive method. Further explained (Banjari et al., 2017) descriptive method is a method that seeks or aims to accurately describe the properties of an individual, circumstance, symptom or group, or determine the frequency or spread of a symptom that has something to do with one symptom and another in society.

Dijelaskan (Jalaluddin, 2004), Descriptive research does not seek or explain relationships, does not test hypotheses or make predictions. Some authors extend descriptive research to any research other than historical and experimental research. Research like this requires adequate qualifications, first; researchers must have receptive properties. He should always be looking, not testing. Second; he must have integrative power, the power to combine the various kinds of information he receives into one unified interpretation. Research related to the Use of Online Media as a Means of Marketing Communication UMKM Actors In The City of Bandung does not test certain theories and also does not make a preliminary conclusion, this study outlines the findings in the field related to the cadas and symptoms of MSMEs in the city of Bandung descriptively.

\section{RESULTS AND DISCUSSION}

Micro, small and medium enterprises are currently the economic drivers that can be taken into account, the existence of micro, 
small and medium enterprises (MSMEs) is a counterbalance to general economic activities because in general business activities in the MSME sector are resistant to the impact of changes in global business patterns. MSME actors in the city of Bandung at this time quite a lot, according to data from the office of micro and medium enterprises cooperatives in the city of Bandung amounted to 6140 . People of Bandung UMKM in the city of Bandung who were the subject of this study include:

1. Production of hijab / veil with the name of your business unit style_in Hijab.

2. Sambal production with the name of Sambal Judes business unit

3. Culinary production with the name pawon nela business unit

4. Recording production under the name of Home Recording business unit

The type of business that varies in the subject of this study, researchers hope to provide a broad picture of msmes activities in the city of Bandung.

This study describes the findings in the field based on two research objectives, namely:

\section{Marketing methods of MSMEs in Bandung}

Marketing methods of a product is important to be prepared carefully, whether it relates to the plan, strategy, and convey to the decision to implement the marketing method that is considered the most appropriate according to the type of business and the product being marketed. The marketing methods of MSMEs who are the subject of this study are different, the first marketing methods applied by businesses producing hijab / veil.

Along with the development of hijab fashion that continues to increase, yourstyle_in hijab produces instant hijabs that are easier and more comfortable to use. Yourstyle_In hijab always strives to present hijab products that are acceptable to all walks of life, guaranteed product quality, quality safety, and consumer decisions are the top priorities Yourstyle_In Hijab. Market demand for hijab needs is wide open, with this consideration at least adding to the spirit and passion of hijab businesses in the city of Bandung. The average number of hijab sales conducted offline as much as 105 pieces per / week, and the average online sales as much as 245 pieces per / week. Sales data with different marketing methods there is a significant difference, namely more sales made online.

This fairly good market demand can certainly influence other businesses to produce similar products so that a proper strategy is needed so as to take the hearts of consumers in making a decision.

Yourstyle_in offers products that suit the era and also the trend that is crowded in the community, with this method is intended to keep positioning itself on a trendy product so as to get opportunities in competing with similar businesses. Through the mission of providing good service, creating innovation in each product, providing affordable prices but quality products will strengthen the company's commitment in maintaining its good name and can compete healthily with other entrepreneurs.

Marketing products from yourstyle_in hijab pay attention to various aspects, including:

a. Products

Introducing the ingredients and advantages of hijab yourstyle_in products to consumers is considered very important, this is certainly so that consumers are interested in buying and even becoming loyal customers. This method of product introduction is done by providing a description on the finished product image/photo uploaded on social media that is used for promotion related to the material and type of fabric used in the production of hijab / veil. Through these ways consumers are more confident and confident in the quality of the products marketed.

b. Place

Choosing a strategic place in marketing a product becomes a very important factor, because in this way it will be easier to get consumers. This strategic criterion is generally with the simple language of the place is easy to reach and can be seen by many people. The place used to market offline is using the private 
residence of the subject of this study, one of the considerations is related to the cost of renting / buying a place and if using a private place can reduce costs. In addition to opening an offline sales place yourstyle_in hijab also market its products through social media instagram, this media has a variety of interesting features and quite effectively reach consumers from various dearah in Indonesia, in addition to using social media, especially Instagram can reduce the cost of promotion can even be suppressed to the cheapest point.

c. Price

The selling price of the product can be a determinant of whether or not the product is marketed because consumers not only see the quality of the product, but the price can be a special consideration. Yourstyle_in hijab has a segmentation of the lower middle class market, thus the price is also adjusted to the class so that it can be reached. The price of the marketed product ranges from Rp. 25,000 to Rp. 35,000 . good quality in its class and also affordable price of this product becomes a lot of choices for hijab users.

d. Promotion

Yourstyle_in hijab promotes its products by utilizing social media Instagram this media selection because it can reach hijab users in Indonesia in general and the city of Bandung in particular. In addition to social media instagram the subject of this study also utilizes social media whatshap to promote its products, the target of the utilization of this media is the people closest to it. To be able to attract more consumers yourstyle_in hijab gives discounts at certain times. Described (Van Dijk, 2013), in Nasrullah in the book Social Media (Nasrullah, 2016), that "Social media is a media platform that focuses on the existence of users who bridge them in activities and collaboration, thus social media can be seen as an online medium (facilitator) that strengthens relationships between users as well as a social bond."

Customer satisfaction is not only limited to good product quality and affordable price, but service is also very important to note. Offline and online sales methods have their own consequences that must be equally considered, yourstyle_in hijab provides a strategy of handling consumer complicity, especially in the delivery of goods. Ordering goods made through online mechanism of goods will be sent through the delivery service, in the process of delivery of goods certainly can not be separated from the constraints / disruptions, at a certain moment (holidays big day, Eid al-Fitr, Christmas, and New Year delays in delivery time often occur, in practice this delay is caused by the delivery service company but it does not want to blame the delivery service because at that moment there is an increase in shipping traffic. Komplen consumers because of delays in delivery of goods, it tries to explain about the delay without blaming certain parties.

The high demand for sambal products makes many restaurants compete in creating the latest innovations regarding the taste of sambal, ranging from sambal based on a mixture of diverse ingredients to sambal based on the level of spiciness. Processed sambal products are one of the more selective choices in terms of taste, price, packaging and promotion of the products displayed.

Seeing the considerable market potential, businesses in packaged sambel industry need to develop a good product development strategy and effective marketing this is done to be able to compete in similar business fields. Sambal judes is an individual processed product that is included in the category of MSMEs, this product is produced in the residence of business owners (research subjects) on the batununggal canal road of Bandung city. The development of this processed business is still very new so it does not have many variants of flavors from the production of sambel 
judes, at this time producing sambel with squid flavor. Sambel judes business owner has a vision to be a successful entrepreneur in the culinary field that presents a quality culinary product and can be useful and develop the latest culinary and mission to make Sambel Judes, become the most delicious and best known sambel among the community.

Based on the vision and mission that has been proclaimed by business owners, sambel judes continues to be developed and marketed through various media and marketing strategies. Promotion as an effort to market products continues to be done either through online media platforms or done offline or conventionally. At the time of online promotion done using social media instagram, the reason for this media selection is the promotional cost of Rp. 0 but can reach most areas of Indonesia and various segmentation of the market.

In addition to utilizing social media, sambel judes products are promoted also offline word of mouth (word of mouth) with a Pre-Order system that is by offering its products to visitors of its stalls, through this way according to the business owner is quite effective, proven many are interested in buying the product. Sambel judes market segmentation is intended for all circles, and the selling price of the product is Rp.25.000/pack. With a fairly affordable price is expected to be a consideration for prospective consumers to buy their products and even become loyal customers of this product sambel judes.

Discussion of objects and subjects of the next research is Pawon Nela, This business activity unit is a business engaged in snacks and falls into the category of MSMEs, this business activity aims to develop a business or home business with the aim to meet the needs of consumers and the product of this business is snack steak. Pawon Nela's target market is all walks of life, of all ages and social issues, starting promotions from around where we live and promoting to friends on social media, as we consider promotions to be more effective if they happen in a group. In addition we also have a production house that is ready to be visited by anyone and ready to serve orders. Online promotion using various social media, such as instagram and also whatsapp. This is intended to make it easier to order and purchase our products.

Promotions conducted by pawon nela using online promotion methods received a positive response, this is seen from the increasing number of buyers compared to offline promotion methods. Pawon nela created a marketing strategy to maximize sales of its products, including:

1. Build a network with influencers

Seeing the change in lifestyle and mindset of humans at this time influencers are considered to have a role and function that is quite influential, with this consideration pawon nela use influencers to promote their products to the public, another consideration with the selection of this strategy is influencers are increasingly easy to find on social media.

2. Creating product innovation and packaging design

Products from pawon nela in the form of snacks that are cystic, processed products have two flavors, namely original flavor steak and spicy taste of orange leaves. This flavor variant becomes differentiating with similar products from other companies or MSMEs products. In addition to the unique flavor variants, pawon nela design attractive packaging and certainly different from existing packaging, with the difference in packaging design in general will be an identity of the product.

3. Improving the quality of service

Service to consumers needs to be improved this is done by pawon nela, as a place for consumers to see a variety of products and as a place 
for consumers to provide website input into the right solution.

\section{Media marketing}

Social media instagram and whatsapp is a popular media among the people of Indonesia, with this consideration pawon nela decided to use this media to promote its products, besides these two social media are not paid or free so as to reduce the cost of promotion.

MSME actors are not only working in the field of business in the form of products, but at this time has begun to penetrate the world of services, especially recording services. World civilization in the field of technology at this time experienced rapid changes, the capacity and function of technology that was previously very limited to certain things but at this time has improved significantly and more cangih. The improvement of the function of technology has an impact on lifestyle and changing human habits so that society in general can become dependent on technology. The last UMKM informant is Steviano, the owner of SGI Studio recording business located in galunggung in Bandung, the development of increasingly sophisticated technology is utilized by MSMEs in Bandung to open a recording service business. Background in introducing a musician there are several media that can support in introducing the identity of a musician one of them by using recording or recording, the existence of media like this identity of a musician can be conveyed well to music listeners and other general public.

SGI Studio is an IT-based music and recording instrument making service by maximizing the development of technology today and minimizing existing recording tools without compromising sound quality, and the costs incurred are more economical and affordable to the public at large. Seeing a potential market in the music industry, this informant felt that the idea was more creative and innovative that would open opportunities for the general public at large so that they could work in the field of music without having to be burdened with high costs

\section{Form of MARKETING communication} of MSMEs through online media

Publication of products umkm actors required seriousness and selection of the right media so that the products offered can be recognized by the public at large, and more than that when the public already know the product has hopes of the decision of the community / prospective consumers to decide the action of buying or using the products we offer. To get a positive response from the community related to the products we sell requires a special strategy in communicating the product, choosing the right media and creating the right content is also part of the strategy that needs to be carried out by MSMEs.

Dijelaskan (Saladin, 2003), Marketing communication is an activity that seeks to disseminate information, influence and customize the target market for the company and its products in order to be willing to accept, buy, loyal to the products offered by the company concerned. Based on the explanation can be conveyed that marketing requires a management, which means it needs a good management, proper and effective management.

The form of marketing communication in each MSMEs can certainly be different from each other, it can be based on the background of the products sold, the background of MSMEs business owners, the target market, and the surrounding environment. This study there are four MSME actors as informants, in this discussion will researchers convey the form of marketing communication conducted by the four informants, including:

Your style_in Hijab business activity unit located in Bandung conducts various promotional strategies in marketing its products, media used in its efforts to promote and publish including instagram social media and whatsapp applications. Promotion through social media Instagram by uploading photos of products of various 
types and models, uploaded photos are selected photos taken from various angles this is done to convince consumers of the products they sell. In addition to uploading photos of products, informant your style_in hijab also lists the price, this price is adjusted to the type of material, model, and production costs and the price offered is affordable for all circles, this is in accordance with the target market that has been determined in advance. And the next form of marketing communication from this informant is by uploading testimonials from consumers who have purchased their products, through this way the informant reveals that other consumers will be more interested and reassured by the products they sell.

The second promotional media used is whatsapp social media, this media according to the informant is very practical and easy to use, in addition the promotion using whatsapp social media does not cost much so that some of the promotional costs can be used for other production costs and can reduce production costs in general. Informant posted some photos of hijab products on whatsapp story, in this way the published photos will be seen by many people, the informant added that even if you look at the limited number of people who are in contact with the mobile phone but this method is effective to promote the product and even considered very effective especially who sees those closest to it so that it will be easier to recognize the product and the quality it has.

UMKM sambal products with the name of sambal judes business unit located on Sukamulya Jl.Terusan Batununngal have a marketing strategy through social media instagram and word of mouth. The selection of social media promotion facilities is done with consideration of a wide reach so that the products offered can be seen by many people and in the hope that the products offered are in demand by many consumers. The form of promotion conducted by this informant is by uploading a product photo with a product description containing the name of the goods / products, types, materials, flavors or variants, up to a characteristic of the product it sells thus will be more convincing consumers and interested to order it. In addition to promotion through social media, this informant also offers its products by conventional word of mouth, further informant explained the technicality of this offer is done by offering to visitors his food stalls, through this strategy is considered quite effective to attract consumers because it can directly explain the product description until it can directly answer questions from prospective consumers related to its products. Production of MSMEs sambel judes is produced on a limited basis and if going to buy in large quantities are required to order in advance (pre-order).

Pawon Nela is an MSMEs that produces snacks one of which is the advantage is cystic. This product is marketed through social media instagram and whatsapp, as well as products marketed directly face-to-face in the environment around the production house, these two ways of marketing is done in order to increase sales to the maximum and of course will get more profit. This form of marketing communication conducted by the informant is by promoting its products through product photo uploads accompanied by various captions related to its products on social media instagram and whatsapp. The upload of photos of this product is continuously updated periodically so that it looks serious in marketing its products, thus consumers will be interested to order the products offered.

Recording production with the name of the home recording business unit is a MSMEs that are still very rare but have a lot of creativity to market their products well, by emphasizing on friendly service, manners, and responsible to have some customers who are loyal to the services offered. Products from home recording SGI Studio marketed online through social media instagram and youtube, this is in line with the basic of this company that relies on the power of technology. Marketing through social media instagram is done by uploading videos and narratives related to the products offered, as well as products offered through the youtube network by uploading videos of service 
products offered and examples of the results of its products, thus consumers will be interested to use its services.

\section{CONCLUSION}

Research on the use of online media as a means of marketing communication of msmes in the city of Bandung provides conclusions based on two research objectives; reveal the marketing methods of MSMEs, and describe the form of marketing communication of MSMEs through online media. The discussion in this study describes the marketing methods conducted by MSMEs in the city of Bandung conducted online through social media facilities instagram, whatsapp, and youtube, the background of this social media selection based on a wide market reach and very cheap promotional prices. In addition to online marketing conducted by these informants using offline or face-to-face methods, one of the strongest reasons when choosing offline is more emphasis on consumers and especially with consumers close to the production house. The form of marketing communication set by the informants in this study is by uploading photos of products (services and goods) accompanied by photo captions, photo captions of these products that can convince consumers to buy the products offered. In contrast to offline marketing forms tend to be simpler because it can directly offer its products to personal consumers, and can directly explain the questions asked by consumers related to the product. Based on the results of the research from the four subjects of the study can be seen that promotions conducted online have a positive impact, this can be seen from the number of buyers who take advantage of online media bookings in accordance with each social media used by the subjects of the study. Of the two promotional methods used by the subjects in this study, online promotion is considered the most effective in reaching consumers.

\section{REFERENCES}

Banjari, Ines, Misir, Andreja, Šavikin, Katarina, Jokić, Stela, Molnar, Maja, De Zoysa, H. K. S., \& Waisundara, Viduranga Y. (2017). Antidiabetic effects of Aronia melanocarpa and its other therapeutic properties. Frontiers in Nutrition, 4, 53. Google Scholar

Jalaluddin, Rakhmat. (2004). Metode penelitian komunikasi. Dilengkapi Contoh Analisis Statistik. Bandung: PT. Redmaja Rosdakarya. Google Scholar

Nasrullah, Rulli. (2016). Teori dan riset media siber (cybermedia). Kencana. Google Book

Panuju, Redi. (2019). Komunikasi Pemasaran: Pemasaran sebagai Gejala Komunikasi Komunikasi sebagai Strategi Pemasaran. Prenada Media. Google Scholar

Saladin, Djaslim. (2003). Manajemen Pemasaran, Analisis, Perencanaan, Pelaksanaan dan Pengendalian. Bandung: Linda Karya. Google Scholar

Suliyanto, S. E., \& MM, Suliyanto. (2017). Metode Penelitian Kuantitatif. Google Scholar

Suryadi, Edi. (2018). Strategi Komunikasi Sebuah Analisis Teori dan Praktis di Era Global. Bandung: Remaja Rosdakarya. Google Scholar

Suwatno. (2018). Komunikasi Pemasaran Kontekstual. Bandung. Simbiosa Rekatama Media.

Fani, Annisya (2018) Strategi Komunikasi Pemasaran Online Shop Babyeye_Id Melalui Aplikasi Instagram Dalam Meningkatkan Penjualan Produk. Universitas Muhammadiyah Sumatera Utara. Google Scholar

Van Dijk, Teun A. (2013). News analysis: Case studies of international and national news in the press. Routledge. Google Book 


\section{Copyright holder:}

Hasim (2021)

First publication right:

Journal of Social Science (JSS)

This article is licensed under:

(c) $\underset{\mathrm{EY}}{(\mathrm{i})}$ (2) 